\title{
Mihailo Petrović Alas' contribution to development of interest for mathematics
}

Summary: Apart from his great creative work in mathematical science, Mihailo Petrović Alas, one of the greatest Serbian mathematicians, managed to write several works of methodological character which were intended for teachers at elementary and secondary schools. In these works Mihailo Petrovićs aim was to popularize mathematics and show how teachers can also be creative and inventors within the domain of teaching. We give an overview of these works in our paper and acquaint the readers in detail with his interesting application of the Pythagorean theorem. A short retrospect of the complete scientific and pedagogical opus of Mihailo Petrović Alas will also be given in the paper.

Keywords: Mihailo Petrović Alas, Pythagorean theorem, pedagogical work, mathematics, popularization of mathematics.

\section{Introduction}

In the year 2018, scientists, and especially mathematicians, in Serbia marked the $150^{\text {th }}$ anniversary of the birth of an important Serbian mathematician Mihailo Petrović Alas (1868-1943). The Serbian Academy of Science and Art, whose regular member was Mihailo Petrović Alas, participated in the events related to this jubilee. There was an exhibition in the Gallery of the Serbian Academy of Science and Art, accompanied by video presentations, where numerous works, books and patents of this great mathematician were exhibited. Apart from the great scientific contribution of Mihailo Petrović Alas, particularly to the mathematics science in Serbia, there is also one, perhaps less visible, but for the teachers of mathematics and students at secondary schools very important contribution demonstrated in the works intended just for this population. Professor Dragan Trifunović, bibliographer of Mihailo Petrović Alas, has quoted 45 works of Mihailo Petrović (Trifunović, 1982), which were written for the teaching of mathematics. We will focus on several works which were published, as additional material, in five geometry textbooks (for grades 1

1 mirko.dejic@gmail.com

Copyright $\odot 2020$ by the authors, licensee Teacher Education Faculty University of Belgrade, SERBIA.

This is an open access article distributed under the terms of the Creative Commons Attribution License (CC BY 4.0) (https://creativecommons.org/licenses/by/4.0/), which permits unrestricted use, distribution, and reproduction in any medium, provided the original paper is accurately cited. 
(1940), 2 (1937), 3 (1938), 4 (1939) and 5 (1944) of secondary school, by authors Anton Bilimović and Tatomir Anđelić. These works enriched mathematics instruction at secondary-school level and contributed to the methodological quality of the textbooks. The titles of these works are: Varljivost oka pri upoređivanju duži i površina (Eyes can deceive us when comparing line segments and spaces; Stvarne $i$ prividne geometrijske nemogućnosti (Real and illusory geometrical impossibilities); Zanimljivosti u primenama Pitagorinog pravila (Interesting points in the application of Pythagoras's rule); Pogrešni geometrijski zadaci iz nepažljivo nacrtane slike (Incorrect geometry tasks as a result of incorrectly drawn geometric images); Neodređeni, nemogućni i nepotpuno određeni planimetrijski zadaci (Vague, impossible, and incompletely defined planimetric tasks). All these works were compiled and published by the Association of Mathematicians and Physicists of the Federal Republic of Serbia, entitled Članci (The Articles) (Petrović, 1949). Mihailo Petrović had only one wish in all these quoted works - to awaken and keep an interest in mathematics and popularize it through simple presentation. The works were used as an example of how creative work and creativity can be demonstrated in the field of elementary mathematics. Starting from quite elementary problematic topics, Mihailo Petrović gave original contributions.

His article Eyes can deceive us when comparing line segments and spaces (Petrović, 1949) shows to pupils and teachers in a simple way that we should be careful while observing and making approximate comparisons because our eyes can often deceive us. Mihailo Petrović Alas points out that there is no room for incorrect conclusions if we pay attention to what is being observed, instead of jumping at conclusions from our first impressions (Petrović, 1949: 12). Further on, Petrović provides many examples to show how our own eyes can trick us.

In the article Real and illusory geometrical impossibilities (Petrović, 1949) the author explains that some problems may arise while observing many geometrical images. Some of these problems may seem solvable, while, in fact, they are insolvable, or vice versa, they may seem insolvable, but in fact they have their solution. The problems of the first kind are real geometrical impossibilities, and the problems of the second kind are illusory geometrical impossibilities. Petrović provides several examples of this kind in his work.

The article Interesting points in the application of Pythagoras's rule (Petrović, 1949) some problems that may appear meaningless and impossible, turn out not to be so when Pythagorean theorem is applied. We are going to elaborate on and analyze this article in detail further on in the paper.

In the article Incorrect geometry tasks as a result of incorrectly drawn geometric images (Petrović, 1949), Petrović gives several examples to point out how one small, at first glance meaningless incorrectness, that is often even impossible to notice in a drawing, can lead to completely wrong and incorrect geometrical conclusions, although the image is interpreted in the most correct and proper way. Đokić et al. $(2019,2020)$ observes that in the work of Mihailo Petrović Alas the precise drawing enables us to see the details that we otherwise would not pay attention to. Mihailo Petrović Alas provides the correct construction of a geometric shape because a wrong construction results in incorrect geometric conclusions.

In his article entitled Vague, impossible, and incompletely defined planimetric tasks (Petrović, 1949) Petrović writes that, at first glance, many planimetric problems may seem meaningless, i.e., impossible. However, solving the tasks by computing, despite their apparent vagueness, shows that they make sense. That kind of task could be the following one (one of the three tasks that Petrović uses to illustrate the above-mentioned situation): Knowing only the sum $S$ of the two legs $a$ and $b$ of a right-angle triangle, calculate its hypotenuse $x$. At first glance this task seems pointless and undefined because if a hypotenuse could be calculated by the legs, both 
legs should be known separately, not only their sum. Petrović shows that everything is not as it seems. As it were, the task has not been completely defined, but it has not been completely undefined either. We can, however, say something about the hypotenuse that is not so obvious.

\section{Mihailo Petrović Alas and his scientific and pedagogical contribution}

Natural development of the Serbian Empire was stopped in the XIV century by Turkish invasion and Serbian countries were under foreign occupation until the 19th century. Although some Serbian areas regained independence a bit earlier, the actual independence of Serbia was achieved at the Berlin Congress in 1878. Mathematics as a particular subject started to be taught in Serbia in 1808 when the so-called Higher School (Velika škola) was established in Belgrade. We should also look here for the roots of the present-day University of Serbia. This school operated until 1813, during the reign of Karađorđe (Đorđe Petrović $\otimes$ Karađorđe, 1768-1817), and was renewed later, during the reign of Miloš (Miloš Obrenović 1789-1860) in the year 1830, and operated in Belgrade until 1833, when it was moved to the city of Kragujevac. The college named the Lyceum was founded in Kragujevac in 1838 and moved to Belgrade in 1841. Mathematics was taught as a separate subject at the Lyceum. Mathematics subject matter taught at the Higher School and the Lyceum was very basic, which is evident from the textbooks of mathematics used at that time. During the rule of Mihailo Obrenović (1823-1868) the Lyceum was reformed (1863). The existing classes/departments at the Lyceum developed into faculties at the Higher School: Faculty of Philosophy, Law Faculty and Technical Faculty. Two departments were established at the Faculty of Philosophy: History - Philology Department and the Faculty of Sciences in the year 1873. The Faculty of Sciences remained at the Faculty of Philosophy until 1947, when it became an independent faculty. Under the Law on University, which took effect in 1905, the Higher School became university. As we can see, the main changes at university level occurred in the 19th century. In this period, several Serbian mathematicians acquired doctorates at foreign universities and then returned to Serbia, worked at the Higher School, and, based on their scientific and pedagogical work, they established the so-called Belgrade Mathematical School. Serbian mathematician Dimitrije Danić (1862-1932) was the first Serb with a PhD in Mathematical Sciences. Apart from him, four other Serbs received a $\mathrm{PhD}$ in Mathematics in the 19th century: Bogdan Gavrilović (1864-1947), Đorđe Petković (18??-19??), Mihailo Petrović (1868-1943) and Petar Vukićević (1862-?). The most famous of them was Mihailo Petrović. He was born in Belgrade, where he completed high school and the studies of natural and mathematical sciences at the Higher School in Belgrade. After he had passed the entrance examination, he was admitted to the Ecole Normale Superieure in Paris in 1890. He defended his doctorate in 1894 in front of the commission consisting of great mathematicians Hermite (Hermite Charles, 1822-1901), Picard (Charles Emile Picard, 18561941) and Painleve (Painleve Paul, 1863-1933). He returned to Belgrade and taught mathematics there for more than 40 years (1894-1938) at the Higher School and the University of Belgrade. It is interesting that he taught 16 different courses. He was the only one who was in charge of doctoral studies at the University of Belgrade from 1912 to 1941. In 1897 he was elected first a corresponding member, and in 1899 a full member of the Academy of Science. Until 1905 he wrote 60 scientific papers, published mostly in foreign scientific journals. He acquired a worldwide fame for his work in the field of mathematics and he also promoted the Serbian School of Mathematics. He was a member of several Academies of Sciences, as well as scientific and professional associations in the world, a participant at more than 40 congresses, recipient of many awards, etc. The creative work of Mihailo Petrović is immense. 
The specific feature of that creative work is evident in his contribution to the very essence of a problem and in revealing and connecting disparate facts. In accordance with Petrovićs determination to search for analogies among disparate phenomena, he was prolific in many different areas: in mathematics he deals with differential equities, the theory of special functions, algebra, theory of probability, arithmetic, differential and integral calculus, geometry, numerical mathematics etc.; he is an inventor of a depth gauge, automatic gear, range finder, calculating machines (chemical calculators, kinematic calculators, hydraulic calculating machines); like Descartes and Leibniz, he looked for common elements in disparate phenomena and created mathematical and general phenomenology. He creates in the field of mechanics, astronomy, physics and chemistry; he writes novels, travelogues and essays, as well as books on fishing, economy, history and law (Vujisić et al., 2011).

Apart from such a huge and rich creative opus, Mihailo Petrović Alas also found time, although he did not work at elementary and secondary schools, to work on issues related to teaching mathematics and he published some fifty papers on this topic. He was connected to teaching in other ways as well: he was our first representative at the International Commission for Teaching Mathematics, he was a member of the Main Educational Advisory Council of the Kingdom of Serbia (later Yugoslavia), the main supervisor of all schools in Serbia, member of the Commission for the Professional Certification of Teachers of Mathematics in secondary schools, he wrote essays on textbooks for secondary schools and reviews of secondary school textbooks, etc.

Perhaps the following quote from the book by Milutin Milanković and Jablan Mihailović describes Petrović best as a scientist and a creative human being:

"In his scientific pursuits, Mihailo Petrović travelled through all the wide realm of mathematical science, without worrying about its regional divi- sions. Thus Mihailo Petrović created mathematical sciences within their interiors and expanded them to their circumferences. All his works have a stamp of originality; they set and solve new problems, create new methods and find new connections. His genius intuition was a powerful source of his works. That source, till his last breath, did not stir nor dry up, and that is why he could enrich mathematical sciences with a sumptuous treasure of new knowledge. He created that treasure for science, not for himself. He never thought of making personal gains, getting advantages, honors and fame. This was one of the best traits of his character and of his entire work".

\section{Application of Pythagorean rule in an interesting way}

There are different ways to interest and motivate children for learning mathematics. One powerful way is to find examples of application of the already covered curriculum, so that children can conclude that the covered material means something or it has interesting and unusual application.

In his interesting articles written for students and teachers at secondary schools, Petrović certainly wanted to show how mathematics can be learnt in an engaging way through its application. In other words, to show how pupils can understand that all what they have learnt involves deeper relationships and connections than it can be observed at first

2 „Svojim naučnim radom prokrstario je Mihailo Petrović celu široku državu matematičkih nauka, ne brinući se za njenu oblasnu podelu. Tako je Mihailo Petrović izrađivao matematičke nauke u njihovoj unutrašnjosti i proširivao ih na njihove periferije. Svi njegovi radovi nose pečat originalnosti, oni postavljaju i rešavaju nove probleme, stvaraju nove metode i pronalaze nove veze. Njegova genijalna intuicija bila je bujno vrelo iz koga je crpeo svoje radove. Taj se izvor nije, do poslednjeg daha njegovog, zamućivao ni presušivao i zato je mogao da matematičke nauke obogati bogatom riznicom novih tekovina. On je tu riznicu privređivao za nauku, a ne za sebe. Jer mu nikada nije ni na um padalo da izvuče lične koristi, počasti i slavlja. To je bila jedna od najlepših crta njegovog karaktera i celokupnog njegovog rada” (Milanković, Mihailović, 1946: 68-69). 
glance. There was also something else that Mihailo Petrović wanted to demonstrate. It was his wish to show that, although it was the matter of completely elementary mathematics, new contributions could be made there as well. Let us illustrate this with two examples in the article Interesting points in the application of Pythagoras's rule (Petrović, 1949). What is problematic in these examples is that the task seems impossible, sometimes even meaningless, but when the Pythagorean theorem is applied, it turns out to be possible and meaningful. This kind of situation boosts pupils' interest in the problem and creates a wish to solve the problem.

\section{I}

A circle of greater diameter could be pulled through the given circular opening, and at the same time the diameter of the circular opening is not to be enlarged.

On a piece of hard paper we trace a circle and draw two parallel tangents AM, BO and one straight line parallel to them, through the center of the circle. Cut a circular roll NQLRN, so that at that place there remains a circular cut whose diameter is equal to the diameter $d$ of the circle (Figure 1).

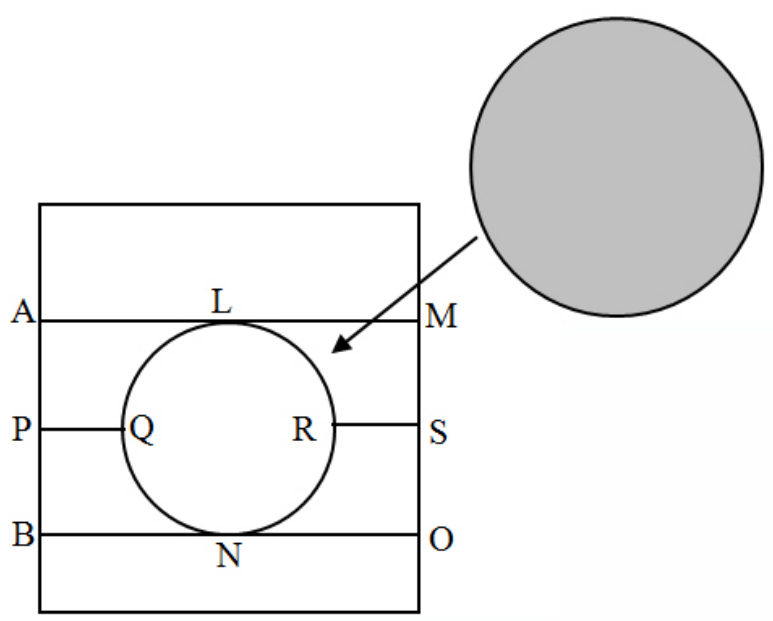

Figure 1. NQLRN circular opening of diameter d on a hard paper through which we pull out a circle of greater diameter.
Now fold the paper along the tangents AM, $\mathrm{BO}$ and their axis of symmetry PQRS so that semicircles QLR and QNR coincide (Figure 2).

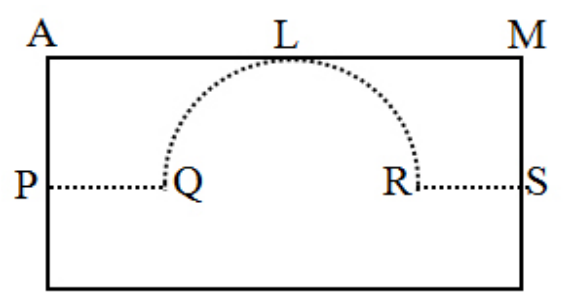

Figure 2. Paper is folded along the axis of symmetry PQRS.

By drawing upwards of the part RS and bringing it into the position as in Figure 3 on the paper, there appears a cut QR which is greater than the cut QR in Figure 1.

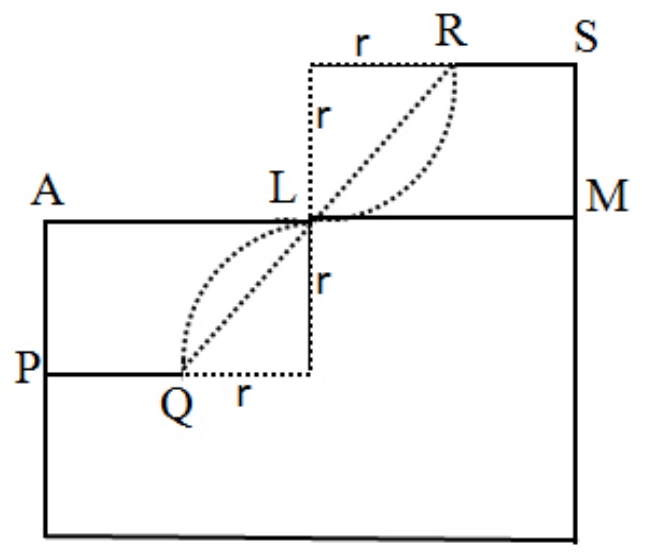

Figure 3. By drawing upwards of the part RS, there appears a cut $Q R$ which is greater than diameter $d$ of the circular opening.

In Figure 3 we can see that the line segment QR is a diagonal of a square whose side equals to the diameter of given circle. Out of this it follows that

$$
Q R=d \sqrt{2} .
$$

We can see that out of circular diameter $\mathrm{d}$ a straight cut line was made: without any enlarging of the circle, whose length is $d \sqrt{2}$. 
Enlargement of the newly obtained cut QR from the original diameter $\mathrm{d}$ is

$$
d \sqrt{2}-d=(\sqrt{2}-1) d=0.4142 \ldots d \approx 0.4 d \text {. }
$$

The cut was enlarged for a bit more than twofifths of its original length.

The task can be phrased in the following way as well: through any non-flexible circular opening in the above quoted way, an unbending, inflexible circular roll could be pulled through whose surface is two times larger than the surface of the opening itself. This is easy to prove.

\section{II}

Through a non-squeezable hard cube a canal should be cut, through which another one, bigger, non-squeezable and hard cube may be pulled through.

Let us put cube $\mathrm{K}$ on a horizontal plane $\mathrm{R}$ so that one of its diagonals, for example O'O is vertical. If that cube is watched laterally it looks as in Figure 4.

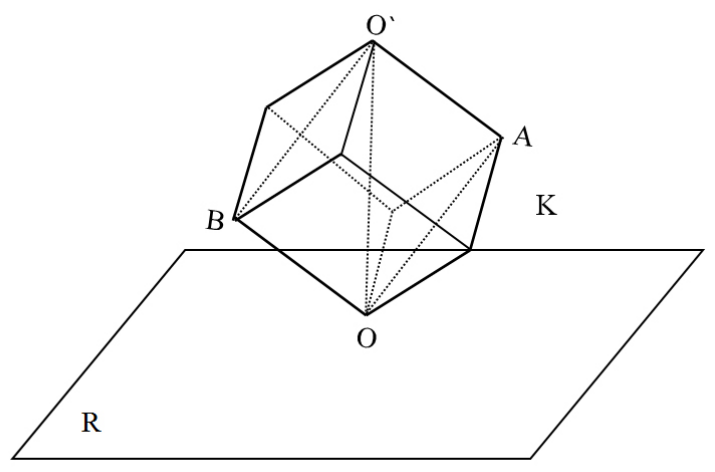

Figure 4. Through a non-squeezable hard cube $\mathrm{Ka}$ canal could be cut, through which another cube, bigger

than $K$, may be pulled through. Diagonal O'O is vertical on horizontal plane $R$.

When this cube is watched from above, the projection of its edges on the plane $\mathrm{R}$ in a shape of regular hexagon $\mathrm{S}$ can be seen, as in Figure 5.

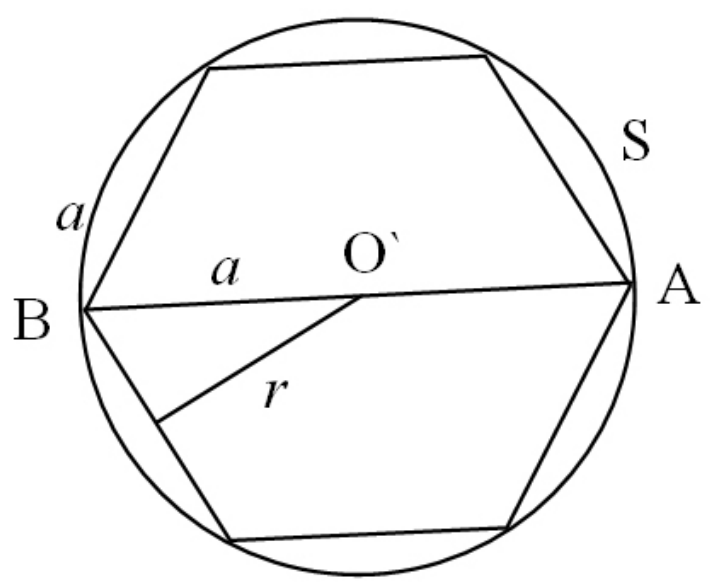

Figure 5. The sides of the regular hexagon represent the edges of cube K projected onto plane $R$.

In order to calculate side $a$ of that hexagon we can use Figure 6 in which the section of the cube $\mathrm{K}$ is seen, which has the shape of the rectangle AO 'BO. One side of that rectangle equals the edge of the cube $\mathrm{K}$ and that length is taken for a unit. The other side equals the length of the side diagonal of the cube. By applying the Pythagorean theorem we calculate that the length of the side OA equals $\sqrt{2}$. Further on, by applying the Pythagorean theorem, we calculate that the diagonal $\mathrm{O}^{\prime} \mathrm{O}$ of that rectangle is $\sqrt{3}$.

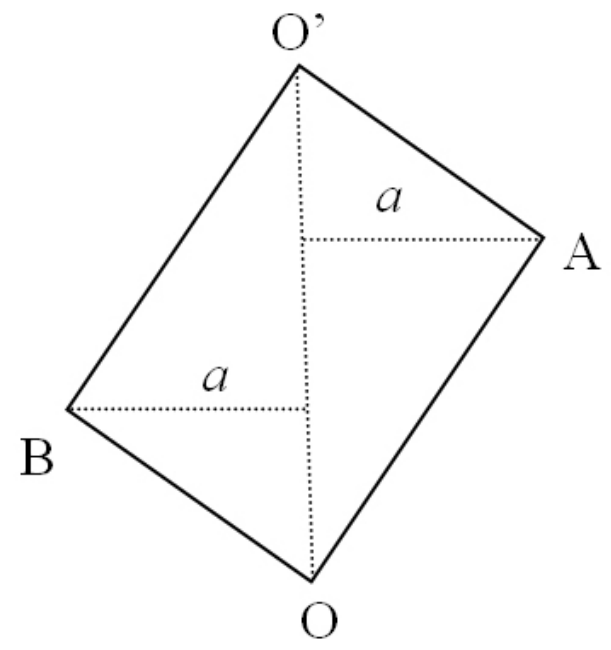

Figure 6. Diagonal cross-section of the cube K. 
In the Figure 6 we can see that the length $a$ is the height of both triangles to which the diagonal $\mathrm{O}$ 'O divides the rectangle. That height can be calculated in the following way. On one side, the surface of the rectangle in Figure 6 is:

$$
1 \cdot \sqrt{2}=\sqrt{2} \text {. }
$$

On the other hand, the surface of the rectangle can also be presented as a sum of the surfaces of two identical triangles that make it. Both these triangles have a mutual base $O^{\prime} O=\sqrt{3}$ and the same heights $a$. If observed in this manner, the surface of the rectangle is $a \sqrt{3}$. When the surfaces are equalized, it follows that

$$
a \sqrt{3}=\sqrt{2} .
$$

Out of this it follows that

$$
a=\frac{\sqrt{2}}{\sqrt{3}} \text {. }
$$

Let us determine a radius of the circle inscribed into our hexagon (Figure 7). It is known that

$$
\begin{aligned}
& r=\frac{1}{2} a \sqrt{3}, \text { in other words } \\
& r=\frac{1}{2} \cdot \frac{\sqrt{2}}{\sqrt{3}} \cdot \sqrt{3}=\frac{\sqrt{2}}{2} .
\end{aligned}
$$

Let us determine a side of the square inscribed into that circle (Figure 7). That side is in fact a hypotenuse of an equilateral right-angled triangle with the leg $r$. Its length is $r \sqrt{2}$. By changing the value of $r$, we get that the length of the side of the observed inscribed square is

$$
\frac{\sqrt{2}}{2} \cdot \sqrt{2}=1 \text {. }
$$

Thus, the side of the square inscribed into this circle is equal to the length of the edge of our cube.

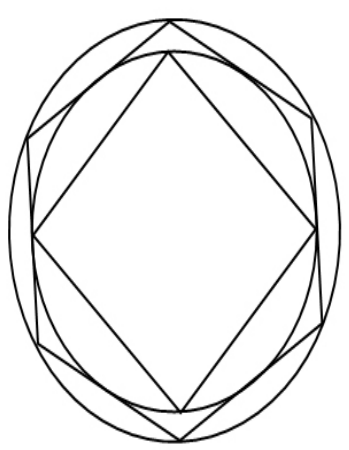

Figure 7. The inscribed square is congruent to the face of the cube $K$.

If from position (Figure 7) where two apices of the square lie on the perimeter of a hexagon we turn the square for 15 degrees, it will come to a new position as in Figure 8 in which neither apexes of the square lie on the perimeter of the hexagon. In other words, that picture shows that between the perimeter of the square and the perimeter of the regular hexagon there are distances everywhere. Therefore, we can enlarge our square more, so it can be put into the regular hexagon. If we make now a canal in our cube in the direction of the diagonal O'O with the section of the size of the square enlarged like this, then a cube even larger than our original cube can pass through that canal.

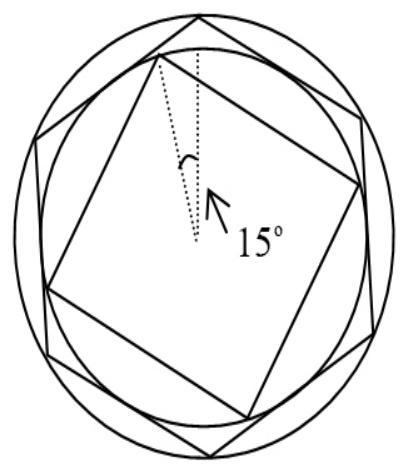

Figure 8. If from position in Figure 7 we rotate the square for 15 degrees, it's sides can be enlarged. We get opening through which cube larger than cube $K$ can be pulled out. 


\section{Conclusion}

We wished to illustrate one segment of the creative work of our great mathematician Mihailo Petrović Alas. For Petrović himself this segment of his work was limited in scope, which means that he wrote these papers for specific purposes, i.e., only for geometry textbooks written by national authors. However, although it seems that these are ordinary examples which our great mathematician created for teachers and students at secondary schools, these examples show his great commitment and inspire teachers to be creators in their pedagogical work. The history of mathematics is full of examples that can be used and modernized in order to be interesting to children and develop their love for mathematics (Dejić, 2019). Together with their teachers, pupils can analyze examples, come up with solutions to those of other students before them, make models, etc. The pupils will gladly make models and pull a greater circle through a smaller opening, or pull a bigger cube through the opening in the smaller cube. They would like to impress the others, but also to show them the mathematical apparatus which led them to the construction of these models. If the examples provided by our mathematicians are available to students, they will develop a stronger sense of patriotism.

\section{References}

- Dejić, M. (2019). Mathematics, its history and teaching. In: S. Lawrence, A. Mihajlović, \& O. Đokić (Eds.). Proceedings of the Training Conference History of Mathematics in Mathematics Education (5-11). October 26-30, 2018, Jagodina, Serbia. Jagodina: Fakultet pedagoških nauka.

- Đokić, O., Jelić, M. \& Ilić, S. (2019). The Relationship between Images and Concepts in the Initial Geometry Teaching. In: Lawrence, S., Mihajlović, A. \& Đokić, O. (Eds.). Proceedings of the Training Conference History of Mathematics in Mathematics Education (29-40). October 26-30. 2018, Jagodina, Serbia. Jagodina: Fakultet pedagoških nauka.

- Đokić, O., Jelić, M. \& Ilić, S. (2020). The Correlation between Figural and Conceptual Properties of Angle and Cube in Pre-Service Teachers Geometric Reasoning. Teaching Innovations, 33 (1), 1-20, DOI: 10.5937/ inovacije2001001D.

- Milanković, M., Mihailović, J. (1946). Mika Alas. Beograd: Kosmos. [Mika Alas] [in Serbian]

- Petrović, M. (1949). Članci. Priredio Vojin Dajović. Beograd: Naučna knjiga. [Articles] [in Serbian]

- Trifunović, D. (1982). Mihailo Petrović Alas. Gornji Milanovac: Dečje novine. [Mihailo Petrović Alas] [in Serbian].

- Vujisić-Živković, N., Dejić, M. i Zeljić, M. (2011). Razvoj metodike osnovnoškolske nastave računice u Kneževini (Kraljevini) Srbiji u XIX veku. U: Antović, N. (ur.). Iz istorije nastave matematike u osnovnim $i$ srednjim školama u Srbiji (41-88). Beograd: Pedagoški muzej. [Development of the methodology of elementary school calculus in the principality (kingdom) of Serbia in the 19th century] [in Serbian] 


\section{Мирко Р. Дејић}

Универзитет у Београду, Учитељски факултет, Београд, Србија

\section{ДОПРИНОС МИХАИЛА ПЕТРОВИЋА АЛАСА РАЗВИЈАЊУ ИНТЕРЕСОВАЊА ЗА МАТЕМАТИКУ}

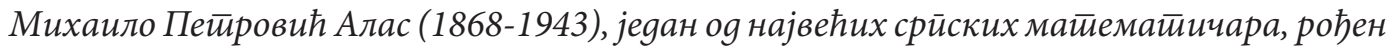

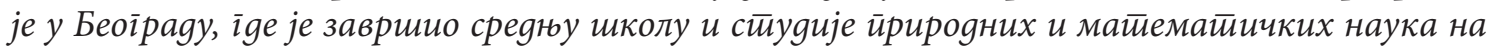

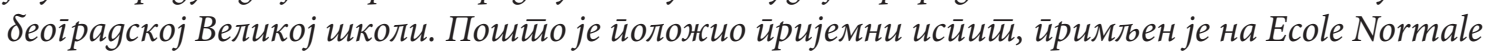
Superieure у Паризу 1890. іолине. Докӣорску йезу оgбранио је 1894. їоgине ӣреg комисијом коју су чинили чувени матиематиччари Ермити (Hermite Charles, 1822-1901), Пикар (Charles Emile Picard, 1856-1941) и Пенлеве (Painleve Paul, 1863-1933). Свейску славу сииекао је за свој

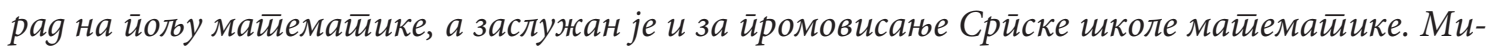

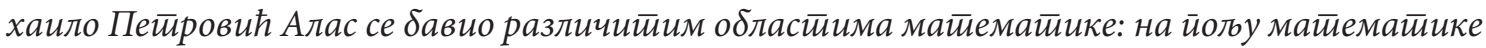

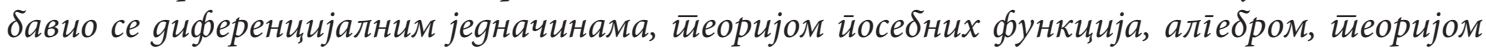

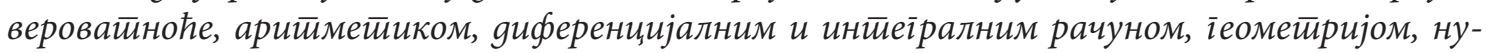

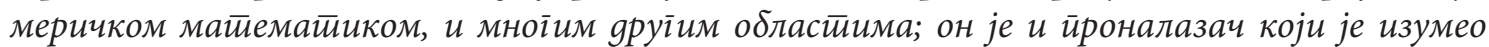
gубиномер, ауйомайски меньч брзина, gалинар, као и рачунске машине (хемијски калкула-

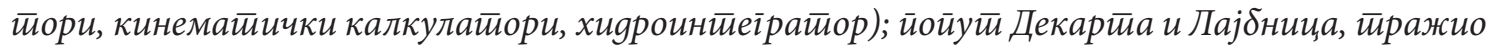

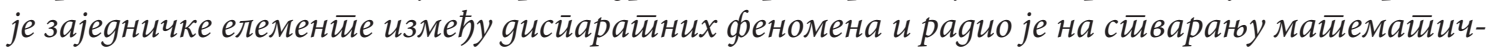
ке и оитите феноменолоїије. Био је сииваралаи, на йолу механике, астирономије, физике и хемије; као йисаи, иичсао је романе, йуйойисе и есеје, али и кюиїе о риболову, економији, ис-

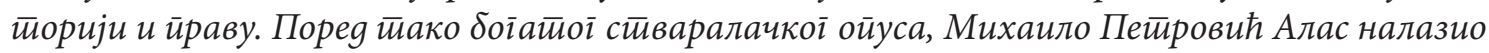
је времена, иако није раяио као иррофесор у основној и среgюој иколи, gа се бави ииийғима

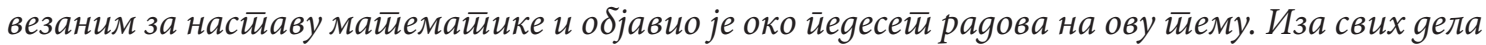
и раяова Михаила Петировића Аласа ойссаних у овом раgу, крила се само јеgна жель овоі

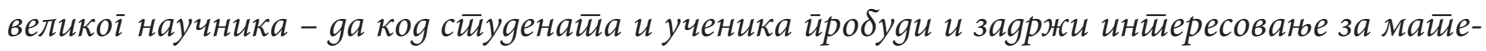

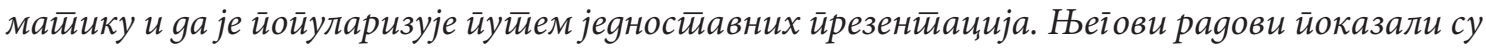

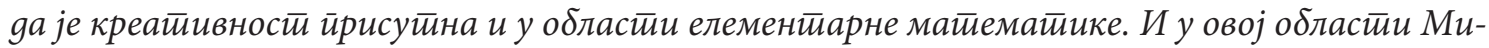
хаило Петрровић Алас gао је тични и ориіинални gойринос. Показаћемо йо на gва иримера

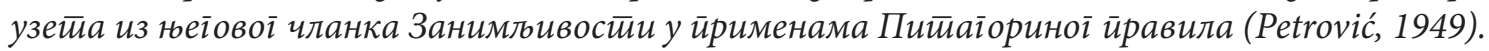
У йрвом ирримеру Петировић иоказује како је кроз ойвор кружноі облика моі̄уће йровући круі чији је ирречник већи оg ирречника кружноі ойвора, а gа се иррийом ирречник кружноі ойвора

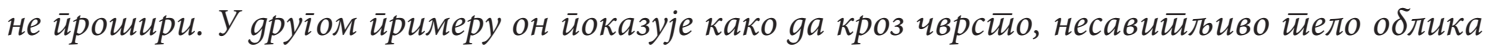
коике иросечемо канал кроз који може gа се ирровуче gруїа, и већа, чврсииа, несавийлива коика.

Иако се чини gа су заgаци у ова gва иримера іотовово бесмислени и gа их је немоїуће

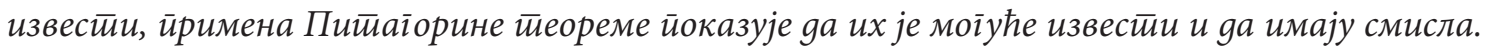

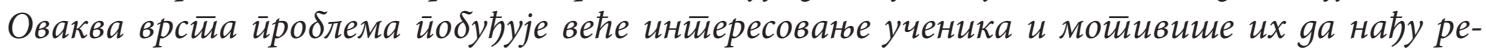
шене. Ови ирримери имају вишестируке иееgаіолке имйликачије. Прва и најважнија је раз-

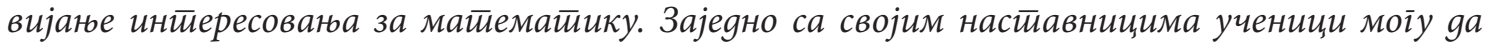
анализирају йримере, ироналазе решена, ираве моgеле, и йоме слично. Ученииима ће се gо- 
йастии gа ирраве моgеле, ирровлаче већи круі кроз маюи ойвор, или gа ирровлаче већу коцку кроз ойвор на маној коцки. Они ће желетии gа остиаве уйисак на gруіе ученике, али и gа им

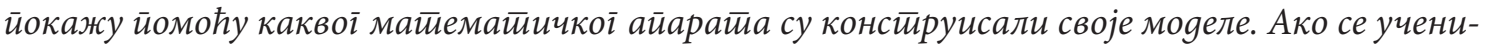

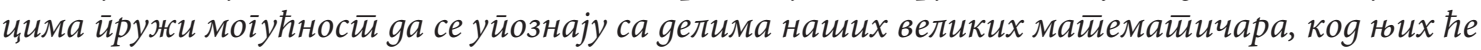
се развитии јача йайриойска осећаньа.

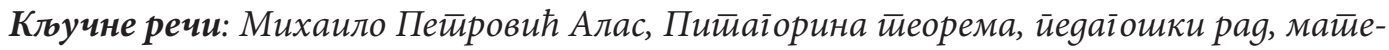

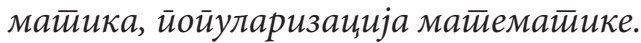

